\title{
Mechanism of production of gait unsteadiness by tumours in the posterior fossa
}

\author{
R. S. MAURICE-WILLIAMS
}

From the Department of Neurosurgery, St Bartholomew's Hospital, London

SYNOPSIS The hypothesis is put forward that the disturbance of gait seen with tumours of the posterior fossa is largely due to subacute dilatation of the ventricular system and not to the involvement of midline cerebellar structures concerned with balance or the coordination of truncal muscles, as is widely taught. This hypothesis is examined in the light of the clinical evidence provided by the symptomatology and treatment of 19 consecutive cases of intracranial mass lesions exhibiting truncal ataxia.

It is well known that a disturbance of gait, often termed 'truncal ataxia' or 'dysequilibrium' occurs with mass lesions situated in the cerebellar vermis, and it is widely held that its presence is of value in localizing a tumour to that region of the brain. The mechanism by which the gait disorder is produced has long been believed to be by involvement of those midline structures of the cerebellum thought to be concerned with balance and with the coordination of truncal muscles. On the basis of clinical evidence, this paper postulates an alternative theory. It suggests that the truncal ataxia of posterior fossa tumours is largely the consequence of acute or subacute hydrocephalus-dilatation of the ventricular system.

The evidence for this alternative theory may be simply summarized as follows: cases of intracranial tumour where truncal ataxia occurs will be found to have dilatation of the lateral ventricles, whether or not the tumour is situated in the cerebellar vermis. Operations which relieve the hydrocephalus will relieve the gait disturbance, even if the tumour is left undisturbed or if its removal causes greater local damage to the cerebellar vermis than that caused by the tumour before operation. It is suggested that the reason why vermis tumours have for so long been believed to cause a gait disturbance by a local effect is that the majority of tumours which give rise to an early hydrocephalus unaccompanied (Accepted 15 August 1974.) by focal signs are, in fact, situated in the midline of the cerebellum - the most striking being the medulloblastomas of childhood.

Truncal ataxia may be defined as a disturbance of gait or balance which cannot be attributed to motor weakness, sensory loss, incoordination of the limbs tested individually, or to a lesion of the vestibular apparatus. It is sometimes referred to as 'dysequilibrium', the presumption in that case apparently being that it is due to a defect of the central mechanisms concerned with balancing, as opposed to one of the central coordinating system for truncal muscles, if such a distinction can be made.

When the possibility that the mechanism of truncal ataxia might be hydrocephalus occurred to the author, a search was made for clinical material to confirm or refute the theory. Over the next two years, 19 consecutive cases of truncal ataxia associated with intracranial tumours were personally observed, 17 at the Guy's-Maudsley Neurosurgical Unit and two at St Bartholomew's Hospital. Brief summaries of these 19 cases are given and their relevant features analysed before the existing literature on the gait disturbances of cerebellar lesions is discussed in relation to them (Table).

\section{ANALYSIS OF CASES}

All the cases summarized had a disturbance of gait, varying in severity from a mild unsteadiness to a complete inability to sit or stand unaided. 
TABLE

CLINICAL DETAILS OF 19 PATIENTS

\begin{tabular}{|c|c|c|c|c|c|c|}
\hline Case & $\begin{array}{c}\text { Sex, } \\
\text { age }(a), \\
\text { hosp. no. }\end{array}$ & Symptoms & Signs & $\begin{array}{l}\text { Radiological } \\
\text { investigations }\end{array}$ & Treatment & Sequel \\
\hline 1 & $\begin{array}{l}\text { M } \\
65 \\
\text { GM } 9633\end{array}$ & $\begin{array}{l}2 \text { m-headaches } \\
1 \text { m-unsteady gait, } \\
\text { confusion, weight } \\
\text { loss }\end{array}$ & $\begin{array}{l}\text { Disorientated. Papil- } \\
\text { loedema. Nystagmus } \\
\text { on lateral and up- } \\
\text { ward gaze. Mild } \\
\text { cerebellar type } \\
\text { ataxia of R limbs. } \\
\text { Unable to sit up or } \\
\text { stand }\end{array}$ & $\begin{array}{l}\text { Ventriculography: } \\
\text { hydrocephalus and } \\
\text { mass in } \mathbf{R} \text { cerebellar } \\
\text { hemisphere }\end{array}$ & $\begin{array}{l}\text { Metastasis removed } \\
\text { from } \mathbf{R} \text { cerebellar } \\
\text { hemisphere }\end{array}$ & $\begin{array}{l}20 \text { d postop.: no } \\
\text { longer confused and } \\
\text { walking unaided, } \\
\text { though ataxia of } \\
R \text { limbs unchanged }\end{array}$ \\
\hline 2 & $\begin{array}{l}\text { F } \\
47 \\
\text { GM } 9584\end{array}$ & $\begin{array}{l}1 \text { yr-worsening gait, } \\
\text { unsteadiness. } \\
\text { Vertigo produced } \\
\text { by sudden head } \\
\text { movements. } \\
1 \text { m-headaches }\end{array}$ & $\begin{array}{l}\text { Mental state normal. } \\
\text { No papilloedema. } \\
\text { Nystagmus on } \\
\text { lateral gaze. Gait } \\
\text { very unsteady, } \\
\text { broad-based }\end{array}$ & $\begin{array}{l}\text { Angiography: sym- } \\
\text { metrical hydro- } \\
\text { cephalus; haeman- } \\
\text { gioblastoma in } \\
\text { superior vermis }\end{array}$ & $\begin{array}{l}\text { Total removal of } \\
\text { cystic haemangio- } \\
\text { blastoma deep in } \\
\text { superior vermis }\end{array}$ & $\begin{array}{l}\text { Immediate relief of } \\
\text { headaches and } \\
\text { vertigo; } 2 \text { w post- } \\
\text { op. gait appeared } \\
\text { normal and could } \\
\text { walk heel to toe } \\
\text { with minimal un- } \\
\text { steadiness }\end{array}$ \\
\hline 3 & $\begin{array}{l}\text { M } \\
56 \\
\text { GM } 9568\end{array}$ & $\begin{array}{l}8 \mathrm{~m} \text {-worsening gait. } \\
1 \mathrm{w} \text {-confusion }\end{array}$ & $\begin{array}{l}\text { Disorientated. Papil- } \\
\text { loedema. Nystagmus } \\
\text { on lateral gaze. Mild } \\
\text { cerebellar ataxia of } \\
\text { L limbs. Gait broad- } \\
\text { based, falls back- } \\
\text { wards }\end{array}$ & $\begin{array}{l}\text { Angiography: dilata- } \\
\text { tion of lateral ven- } \\
\text { tricles. Haemangio- } \\
\text { blastoma of } \mathrm{L} \\
\text { cerebellar hemi- } \\
\text { sphere }\end{array}$ & $\begin{array}{l}\text { Total removal of solid } \\
\text { haemangioblastoma } \\
\text { of } \mathbf{L} \text { cerebellar } \\
\text { hemisphere }\end{array}$ & $\begin{array}{l}2 \text { w later confusion } \\
\text { gone, gait greatly } \\
\text { improved. Ataxia of } \\
\text { L limbs unchanged }\end{array}$ \\
\hline 4 & $\begin{array}{l}\text { M } \\
4 \\
\text { GM } 9500\end{array}$ & $\begin{array}{l}3 \text { m-headache, } \\
\text { vomiting }\end{array}$ & $\begin{array}{l}\text { Gait unsteady, broad- } \\
\text { based. Papilloedema }\end{array}$ & $\begin{array}{l}\text { Angiography: dilata- } \\
\text { tion of lateral ven- } \\
\text { tricles; avascular } \\
\text { mass in inferior } \\
\text { vermis }\end{array}$ & $\begin{array}{l}\text { Subtotal removal of } \\
\text { astrocytoma of } \\
\text { inferior vermis }\end{array}$ & $\begin{array}{l}10 \mathrm{~d} \text { postop.: head- } \\
\text { aches gone, papil- } \\
\text { loedema resolving, } \\
\text { gait improved }\end{array}$ \\
\hline 5 & $\begin{array}{l}\text { M } \\
63 \\
\text { GM } 9110\end{array}$ & $\begin{array}{l}3 \mathrm{w} \text {-headaches, fall- } \\
\text { ing around. } \\
5 \mathrm{~d}-\text { confusion and } \\
\text { apathy }\end{array}$ & $\begin{array}{l}\text { Lethargic, confused. } \\
\text { Papilloedema. } \\
\text { Nystagmus on } \\
\text { lateral gaze. No } \\
\text { limb ataxia or } \\
\text { weakness. Unable to } \\
\text { stand, falls back- } \\
\text { wards }\end{array}$ & $\begin{array}{l}\text { Carotid angiography: } \\
\text { symmetrical hydro- } \\
\text { cephalus. Ventriculo- } \\
\text { gram: mass in ver- } \\
\text { mis }\end{array}$ & $\begin{array}{l}\text { Subtotal removal of } \\
\text { metastasis in upper } \\
\text { midline cerebellum } \\
\text { extending into } \mathbf{L} \\
\text { cerebellar hemi- } \\
\text { sphere }\end{array}$ & $\begin{array}{l}3 \text { d later well-orien- } \\
\text { tated, walking un- } \\
\text { aided though now } \\
\text { had moderate ataxia } \\
\text { of } L \text { limbs }\end{array}$ \\
\hline 6 & $\begin{array}{l}\text { F } \\
58 \\
\text { GM } 9408\end{array}$ & $\begin{array}{l}9 \mathrm{~m} \text {-headache. Gait } \\
\text { unsteadiness. Loss } \\
\text { of memory }\end{array}$ & $\begin{array}{l}\text { Well-orientated but } \\
\text { distractable. Mild } \\
\text { ataxia left limbs. } \\
\text { Completely unable } \\
\text { to stand unaided }\end{array}$ & $\begin{array}{l}\text { Angiography: sym- } \\
\text { metrical hydro- } \\
\text { cephalus and avascu- } \\
\text { lar tumour behind L } \\
\text { petrous bone }\end{array}$ & $\begin{array}{l}\text { Subtotal removal of } \\
\text { solid haemangio- } \\
\text { blastoma of } L \text { cere- } \\
\text { bellar hemisphere } \\
\text { extending into } \\
\text { vermis }\end{array}$ & $\begin{array}{l}7 \mathrm{~d} \text { later mental state } \\
\text { normal, no head- } \\
\text { ache and walking } \\
\text { unaided, though } \\
\text { ataxia of } L \text { limbs } \\
\text { was worse }\end{array}$ \\
\hline 7 & $\begin{array}{l}\text { M } \\
25 \\
\text { GM } 8798\end{array}$ & $\begin{array}{l}2 \mathrm{~m} \text {-headache, } \\
\text { vomiting. } \\
2 \text { w-gait deteriora- } \\
\text { ting }\end{array}$ & $\begin{array}{l}\text { Papilloedema. Bi- } \\
\text { lateral sixth nerve } \\
\text { palsies. Mild cere- } \\
\text { bellar ataxia of right } \\
\text { limbs. Gait very } \\
\text { unsteady }\end{array}$ & $\begin{array}{l}\text { Carotid angiogram: } \\
\text { symmetrical hydro- } \\
\text { cephalus. Ventriculo- } \\
\text { graphy: mass in } \mathbf{R} \\
\text { cerebellar hemi- } \\
\text { sphere }\end{array}$ & $\begin{array}{l}\text { ?Total removal of } \\
\text { medulloblastoma in } \\
\text { outer part of } \mathbf{R} \\
\text { cerebellar hemi- } \\
\text { sphere }\end{array}$ & $\begin{array}{l}8 \mathrm{~d} \text { later walking heel } \\
\text { to toe with minimal } \\
\text { clumsiness. } \mathbf{R} \text { limbs } \\
\text { still slightly ataxic }\end{array}$ \\
\hline 8 & $\begin{array}{l}\text { F } \\
7 \\
\text { GM } 8972\end{array}$ & $\begin{array}{l}6 \mathrm{w} \text {-headache, } \\
\text { vomiting, malaise }\end{array}$ & $\begin{array}{l}\text { Papilloedema. Un- } \\
\text { steady on heel to } \\
\text { toe walking }\end{array}$ & $\begin{array}{l}\text { Ventriculography: } \\
\text { hydrocephalus and } \\
\text { mass on } R \text { of pos- } \\
\text { terior fossa }\end{array}$ & $\begin{array}{l}\text { Subtotal removal of } \\
\text { astrocytoma of } \\
\text { inferior vermis and } \\
\mathbf{R} \text { cerebellar hemi- } \\
\text { sphere }\end{array}$ & No signs 2 m post-op. \\
\hline 9 & $\begin{array}{l}\text { M } \\
61 \\
\text { GM } 9142\end{array}$ & $\begin{array}{l}2 \mathrm{~m} \text {-headaches. } \\
\text { Clumsy right hand. } \\
\text { Worsening gait }\end{array}$ & $\begin{array}{l}\text { Confused. Papil- } \\
\text { loedema. Mild limb } \\
\text { ataxia } L>R \text {. Un- } \\
\text { able to sit or stand } \\
\text { unaided }\end{array}$ & $\begin{array}{l}\text { Carotid angiography: } \\
\text { hydrocephalus. } \\
\text { Ventriculography: } \\
\text { mass in inferior } \\
\text { vermis }\end{array}$ & $\begin{array}{l}\text { Partial removal of } \\
\text { vermis glioma ex- } \\
\text { tending into both } \\
\text { cerebellar hemi- } \\
\text { spheres }\end{array}$ & $\begin{array}{l}\text { At } 14 \text { d well orien- } \\
\text { tated and gait vir- } \\
\text { tually normal } \\
1 \text { yr later had re- } \\
\text { lapse of gait ataxia } \\
\text { and confusion. Both } \\
\text { only partially re- } \\
\text { lieved by a ven- } \\
\text { triculoatrial shunt }\end{array}$ \\
\hline 10 & $\begin{array}{l}\text { F } \\
62 \\
\text { GM } 9453\end{array}$ & $\begin{array}{l}6 \text { m-worsening gait. } \\
\text { Mental deteriora- } \\
\text { tion }\end{array}$ & $\begin{array}{l}\text { Disinhibited, confused. } \\
\text { Nystagmus on } \\
\text { lateral and vertical } \\
\text { gaze. Reduced } \mathbf{R} \\
\text { corneal refiex. Un- } \\
\text { able to stand un- } \\
\text { aided }\end{array}$ & $\begin{array}{l}\text { Angiography: hydro- } \\
\text { cephalus and menin- } \\
\text { gioma of } \mathbf{R} \text { petrous } \\
\text { apex }\end{array}$ & Ventriculoatrial shunt & $\begin{array}{l}8 \mathrm{~d} \text { later well-orien- } \\
\text { tated and walking } \\
\text { with assistant }\end{array}$ \\
\hline
\end{tabular}


TABLE-continued

\begin{tabular}{|c|c|c|c|c|c|c|}
\hline Case & $\begin{array}{l}\text { Sex, } \\
\text { age }(y r) \\
\text { hosp. no. }\end{array}$ & Symptoms & Signs & $\begin{array}{l}\text { Radiological } \\
\text { investigations }\end{array}$ & Treatment & Sequel \\
\hline 11 & $\begin{array}{l}\text { F } \\
68 \\
\text { GM } 9352\end{array}$ & $\begin{array}{l}9 \text { m-worsening gait. } \\
\text { Intellectual de- } \\
\text { terioration }\end{array}$ & $\begin{array}{l}\text { Demented. Limitation } \\
\text { of conjugate up- } \\
\text { ward gaze. Sym- } \\
\text { metrically brisk ten- } \\
\text { don reflexes. Slight } \\
\text { ataxia } L \text { arm. Un- } \\
\text { able to stand un- } \\
\text { aided }\end{array}$ & $\begin{array}{l}\text { Pneumoencephalo- } \\
\text { graphy: hydro- } \\
\text { cephalus and pineal } \\
\text { mass }\end{array}$ & $\begin{array}{l}\text { Ventriculoatrial shunt } \\
\text { (no radiotherapy) }\end{array}$ & $\begin{array}{l}5 \text { m later: gait and } \\
\text { mental state normal }\end{array}$ \\
\hline 12 & $\begin{array}{l}\text { M } \\
25 \\
\text { GM } 9376\end{array}$ & $\begin{array}{l}7 \mathrm{~m} \text {-headache. } \\
\text { Worsening gait }\end{array}$ & $\begin{array}{l}\text { Alert, well-orientated. } \\
\text { Bilateral papil- } \\
\text { loedema. Minimal } \\
\text { ataxia L limbs. Gait } \\
\text { unsteady, broad } \\
\text { based }\end{array}$ & $\begin{array}{l}\text { Angiography: hydro- } \\
\text { cephalus, and mass } \\
\text { in superior vermis }\end{array}$ & $\begin{array}{l}\text { Preliminary ventricu- } \\
\text { lar drain. Removal } \\
\text { of tuberculoma of } \\
\text { superior vermis }\end{array}$ & $\begin{array}{l}\text { Gait returned vir- } \\
\text { tually to normal. } \\
\text { L-sided ataxia } \\
\text { worse. Gait im- } \\
\text { provement main- } \\
\text { tained }\end{array}$ \\
\hline 13 & $\begin{array}{l}\text { M } \\
55 \\
\text { GM } 8658\end{array}$ & $\begin{array}{l}9 \mathrm{~m} \text {-headache, } \\
\text { vomiting, drowsi- } \\
\text { ness. } \\
6 \mathrm{~m} \text {-worsening gait }\end{array}$ & $\begin{array}{l}\text { Intellect normal. } \\
\text { Papilloedema. Gross } \\
\text { gait unsteadiness. } \\
\text { Slight spasticity and } \\
\text { weakness left limbs }\end{array}$ & $\begin{array}{l}\text { Ventriculography: } \\
\text { hydrocephalus } \\
\text { caused by anterior } \\
\text { third ventricle } \\
\text { (?thalamic) mass }\end{array}$ & Ventriculoatrial shunt & $\begin{array}{l}\text { Gait returned to vir- } \\
\text { tually normal. } \\
\text { Spastic L hemi- } \\
\text { paresis unaltered. } \\
\text { Relapse of head- } \\
\text { aches and gait un- } \\
\text { steadiness } 6 \text { m later } \\
\text { relieved by revision } \\
\text { of shunt }\end{array}$ \\
\hline 14 & $\begin{array}{l}\text { F } \\
68 \\
\text { GM } 9225\end{array}$ & $\begin{array}{l}1 \text { yr-headaches. } \\
6 \text { m-changed per- } \\
\text { sonality. Worsening } \\
\text { gait }\end{array}$ & $\begin{array}{l}\text { Confused. Papil- } \\
\text { loedema. Impaired } \\
\text { upward gaze. Slight } \\
\text { ataxia } \mathbf{R} \text { arm. Gross } \\
\text { gait unsteadiness }\end{array}$ & $\begin{array}{l}\text { Angiography: hydro- } \\
\text { cephalus, and } \\
\text { avascular mass high } \\
\text { in midline of pos- } \\
\text { terior fossa }\end{array}$ & $\begin{array}{l}\text { Partial removal of } \\
\text { lymphoma on } \\
\text { underside of tentor- } \\
\text { ium }\end{array}$ & $\begin{array}{l}10 \text { d later: well orien- } \\
\text { tated, no headaches, } \\
\text { gait virtually norma }\end{array}$ \\
\hline 15 & $\begin{array}{l}\text { F } \\
61 \\
\text { GM } 8997\end{array}$ & $\begin{array}{l}2 \text { yr-headache, } \\
\text { apathy. Worsening } \\
\text { gait }\end{array}$ & $\begin{array}{l}\text { Confused. Weakness } \\
\text { of conjugate up- } \\
\text { ward gaze. Mild } \\
\text { ataxia L limbs. Un- } \\
\text { able to stand un- } \\
\text { aided }\end{array}$ & $\begin{array}{l}\text { Carotid angiography: } \\
\text { symmetrical hydro- } \\
\text { cephalus. Ventriculo- } \\
\text { graphy: indentation } \\
\text { of posterior third } \\
\text { ventricle }\end{array}$ & $\begin{array}{l}\text { Fenestration of arach- } \\
\text { noid cyst just below } \\
\text { apex of tentorium }\end{array}$ & $\begin{array}{l}12 \text { d later: intellectua } \\
\text { state normal, walk- } \\
\text { ing unaided }\end{array}$ \\
\hline 16 & $\begin{array}{l}\text { F } \\
57 \\
\text { GM } 9975\end{array}$ & $\begin{array}{l}2 \text { m-headache. } \\
\text { Intellectual and } \\
\text { gait deterioration }\end{array}$ & $\begin{array}{l}\text { Confused. Papil- } \\
\text { loedema. Ataxia R } \\
\text { arm. Tendon reflexes } \\
\text { symmetrically brisk } \\
\text { Unable to sit or stand } \\
\text { unaided }\end{array}$ & $\begin{array}{l}\text { Angiography: sym- } \\
\text { metrical hydro- } \\
\text { cephalus and mass } \\
\text { in } \mathbf{R} \text { cerebellar } \\
\text { hemisphere }\end{array}$ & $\begin{array}{l}\text { Ventricular drainage. } \\
\text { Removal of meta- } \\
\text { stasis from } \mathbf{R} \text { cere- } \\
\text { bellar hemisphere }\end{array}$ & $\begin{array}{l}3 \text { d later still confused } \\
\text { but could walk with } \\
\text { assistance. Little fur- } \\
\text { ther improvement }\end{array}$ \\
\hline 17 & $\begin{array}{l}\text { M } \\
58 \\
\text { GM } 8816\end{array}$ & $\begin{array}{l}1 \mathrm{~m} \text {-headache, gait } \\
\text { unsteadiness }\end{array}$ & $\begin{array}{l}\text { Well-orientated. Un- } \\
\text { able to stand unaided }\end{array}$ & $\begin{array}{l}\text { Ventriculography: } \\
\text { symmetrical hydro- } \\
\text { cephalus, mass in L } \\
\text { cerebellar hemi- } \\
\text { sphere }\end{array}$ & $\begin{array}{l}\text { Removal of meta- } \\
\text { stasis from } L \text { cere- } \\
\text { bellar hemisphere }\end{array}$ & Died 2 d later \\
\hline 18 & $\begin{array}{l}\text { F } \\
34 \\
\text { SBH } 531854\end{array}$ & $\begin{array}{l}8 \mathrm{~m} \text {-headache and } \\
\text { gait unsteadiness }\end{array}$ & $\begin{array}{l}\text { Papilloedema. Un- } \\
\text { steady heel to toe } \\
\text { walking }\end{array}$ & $\begin{array}{l}\text { Carotid angiography: } \\
\text { symmetrical hydro- } \\
\text { cephalus. Ventriculo- } \\
\text { graphy: pineal mass }\end{array}$ & Ventriculoatrial shunt & $\begin{array}{l}\text { Headaches and gait } \\
\text { unsteadiness re- } \\
\text { lieved before radio- } \\
\text { therapy }\end{array}$ \\
\hline 19 & $\begin{array}{l}\text { M } \\
25 \\
\text { SBH } 514369\end{array}$ & $\begin{array}{l}9 \mathrm{~m} \text {-vomiting. } \\
4 \mathrm{~m} \text {-gait unsteady. } \\
2 \mathrm{~m} \text {-headache. Di- } \\
\text { plopia }\end{array}$ & $\begin{array}{l}\text { Papilloedema. Nystag- } \\
\text { mus on lateral and } \\
\text { upward gaze. Heel } \\
\text { to toe gait unsteady }\end{array}$ & $\begin{array}{l}\text { Angiography: hydro- } \\
\text { cephalus; avascular } \\
\text { mass in vermis }\end{array}$ & $\begin{array}{l}\text { Partial removal of } \\
\text { medulloblastoma } \\
\text { filling fourth ven- } \\
\text { tricle, to allow free } \\
\text { flow of CSF }\end{array}$ & $\begin{array}{l}\text { Virtually no abnormal- } \\
\text { ity of gait } 14 \mathrm{~d} \text { post- } \\
\text { op. (before com- } \\
\text { mencement of } \\
\text { radiotherapy) }\end{array}$ \\
\hline
\end{tabular}

The quality of the gait disturbance was similar in all, consisting of an appearance of a greater or lesser degree of instability in the upright position. Ten patients had some lateralized limb ataxia of cerebellar type, and two showed pyramidal tract signs, but these did not appear to be of sufficient magnitude to account for the abnormality of gait and balance in the individual cases concerned.
The responsible lesions were situated as follows: midline in the posterior fossa (11), laterally in the posterior fossa (three), pineal region (three), clivus (one), thalamus (one). Their histological nature was varied and of the 17 cases where it was possible to say with certainty, 14 were intrinsic and three extrinsic tumours.

In 18 cases there was radiological evidence of 
ventricular dilatation and in the remaining case, a tumour of one cerebellar hemisphere, there was clear evidence of raised intracranial pressure, and it seems reasonable to infer that hydrocephalus was present. In 15 cases the tumour was so situated that it either involved the vermis directly or it was possible that it might do so from indirect distortion. Seventeen cases showed clinical evidence of hydrocephalus-for example, papilloedema or intellectual dulling-other than the gait disturbance.

Six patients had their hydrocephalus relieved by temporary or permanent ventricular drainage before direct interference with the causative lesion. In all these the former led to improvement in the abnormality of gait: complete resolution in two (cases 11 and 18), moderate relief in two (cases 12 and 13), and partial relief in two (cases 10 and 16). Complete or partial removal of the tumour relieved the hydrocephalus in 13 cases and in seven of these the operation involved, of necessity, considerable damage to the midline structures of the cerebellum. Yet of these seven cases, the disorder of gait recovered totally or nearly so in six and in the remaining case there was partial recovery. In six cases removal of the tumour was apparently achieved without significant trauma to the cerebellar vermis. The gait disturbance recovered totally or almost so in four of these. One case died too soon postoperatively to allow this function to be assessed and in one patient (case 16), a preliminary ventricular drain had already produced a partial recovery of gait which the removal of the tumour, a metastasis in the cerebellar hemisphere, did nothing further to improve.

\section{DISCUSSION}

It is widely taught that a disturbance of gait in the absence of other significant focal neurological signs will localize an intracranial tumour to the cerebellar vermis, and that the vermis contains structures concerned with maintaining balance and coordinating truncal muscles. Authoritative support for this belief may be found in the literature-for example, Holmes (1922), Weisenburg (1927), and Dow (1969).

It is largely based on observations made before the second world war, for as Brodal (1969) has aptly remarked, 'in recent years relatively few authors have been interested in the subject' (of $\stackrel{\mathbb{D}}{\complement}$ cerebellar symptomatology). Gordon Holmes's (1917) study of patients with posterior fossa missile wounds is probably the most comprehensive clinicoanatomical study of this subject. $\mathrm{He}$ came to the conclusion that 'activities which require the cooperation of homologous bilateral muscles are represented in or near the vermis'. Bailey and Cushing (1925) in their study of $\underset{\vec{\rho}}{\vec{F}}$ childhood cerebellar medulloblastomas attri- $\overrightarrow{0}$ buted the gait ataxia which may be an early 음 symptom of these tumours to a postulated origin $\frac{\bar{s}}{7}$ in the flocculonodular lobe, the main cerebellar $\stackrel{\Phi}{\varnothing}$ receiving area for vestibular fibres. This was \% supported by Raaf and Kernohan (1944) who $\vec{\circ}$ found resemblances between medulloblastoma cells and certain embryonal cell rests in that $\vec{\omega}$ part of the cerebellum.

Animal studies involving resections of the $\frac{5}{0}$ caudal vermis were found to cause transient gait $\omega_{\infty}$ disturbances. Dow (1938) resected the nodulus $i v$ and uvula in monkeys, finding that the gait r $r \vec{b} \vec{\omega}$ mained unaffected if a preceding labyrinthectomg $\omega$ had been performed. Carrea and Mettler (194 resected the flocculus alone in monkeys. The produced a less marked and briefer gait un steadiness. The same authors produced a seve gait disturbance, together with gross ataxia of all limbs, by resecting the vermis of the anterio $\overrightarrow{0}$ lobe and lobulus simplex. These findings may or relate to the somatotopical representation of the termination of the spinocerebellar pathways demonstrated by Adrian (1943) in this part of the cerebellum. The hindlimbs are represented most rostrally in this area and it is of interest $\stackrel{\unrhd}{\varrho}$ that alcoholic cerebellar degeneration, which is $\overrightarrow{\overrightarrow{0}}$ characterized by the early development of an 3 ataxic gait, is largely limited to the anterior vermis (Victor et al., 1959). In this condition, unlike the gait ataxia attributed to flocculonodular lobe lesions, the disturbance of gait appears attributable to incoordination of the $\frac{5}{3}$ legs tested individually, correlating with the fact $\bar{\rho}$. that the degeneration begins in the most rostral part of the anterior lobe vermis.

Thus the evidence is that vermis lesions at two sites can produce gait disturbances. Lesions of the caudal vermis (vestibulocerebellum) may lead to dysequilibrium unaccompanied by $\curvearrowright$ limb ataxia, while anterior lobe lesions disturb 오 gait due to ataxia of the individual legs, a type of $\stackrel{N}{\omega}$ 
gait disturbance which does not concern us here. Little is known of the functions of the more central vermis lying between these two extremes (Brodal, 1969), though it is known that visual and auditory stimuli may evoke action potentials there (Snider and Stowell, 1944). Despite the assertions of Bolk (1906) and Weisenburg (1927) it has not been shown that truncal and limb girdle muscles have a special representation in the vermis.

It is not the intention here to dispute that ablations of the caudal vermis disturb gait or that the vestibulocerebellum is concerned with balance, but it is asserted that the clinical gait symptoms observed to accompany posterior fossa tumours are to a large extent (though maybe not completely) the consequence of acute hydrocephalus.

The clinical evidence for relating vermis tumour gait ataxia to vestibulocerebellar damage is based mainly on medulloblastomas. Yet by the time of operation, let alone at necropsy, the tumour is generally involving such an extensive area of the cerebellum and the fourth ventricle that it is not possible to identify it as having arisen in the flocculonodular lobe. The author examined the records of all childhood medulloblastomas treated by a single surgeon (Mr J. J. Maccabe) at the Guy's-Maudsley Neurosurgical Unit. In all cases there was both preoperative gait ataxia and radiological evidence of hydrocephalus. Yet the gait recovered rapidly after operation, which relieved the hydrocephalus by unblocking the fourth ventricle while, if anything, inflicting further damage to the vermis. The onset of a gait disturbance coincided with or succeeded other undoubted symptoms of hydrocephalus, such as headache or lethargy, yet if it were due to flocculonodular lobe damage it might be expected that it would have appeared at an earlier stage, before the fourth ventricle had become blocked.

The evidence that, in man, traumatic lesions of the vermis give rise to a gait ataxia is not convincing. Although Holmes (1917) believed that the vermis is concerned with control of truncal muscles, he was forced to admit that he had never seen a wound confined to the vermis, and that where a wound involved the vermis in addition to a lateral lobe(s) there appeared to be no additional loss of control of gait other than that attributable to incoordination of individual limbs.

Weisenburg (1927) stated revealingly that, though in his experience mistakes in localizing a lesion to the cerebellum have seldom occurred, yet where they have, it has usually been where a hydrocephalus has been caused by, say, a tumour in the third ventricle. An unsteady gait may be a symptom of adult normotensive communicating hydrocephalus (Ojemann, 1972) and even the dominating feature (Chawla and Woodward, 1972). Colloid cysts of the third ventricle may produce a severe gait disturbance which recovers when the cyst is removed and the hydrocephalus is relieved (Little and MacCarty, 1974).

It may well be asked why such an evident feature as gait ataxia has not previously been recognized as one of the symptoms of ventricular dilatation. There are probably several reasons. There is no doubt that hydrocephalus may be unaccompanied by any disorder of gait, especially if its onset is gradual, and early in life. Thus cases of congenital hydrocephalus are seldom characterized by an abnormal gait, though sometimes the latter is prominent. Also it has seemed to the writer that where gait ataxia is present in children with posterior fossa tumours, it is less striking and more easily overlooked than in comparable adult cases.

Until the wide recognition of adult-onset communicating hydrocephalus in the last decade, most cases of hydrocephalus of relatively acute onset recognized in adult life were due to tumours. Many of these were so situated that they produced in addition to the gait ataxia lateralized symptoms such as some spastic weakness or limb cerebellar ataxia. These features were probably often insufficient to account for the gait disturbance, but this was possibly overlooked and a false attribution of the difficulty in walking made to relatively minor clinical abnormalities. Those patients with tumours so situated in the vermis region as to produce hydrocephalus but no focal features had their unstable gait attributed to vermal damage, as that symptom was well known to be pathognomonic of a lesion in that part of the brain!

However, in many cases it seems likely that there is a local component contributing to the gait ataxia, for this symptom is often only par- 
tially relieved by relief of the hydrocephalus. In case 9 the original partial resection of a glioma of the caudal vermis led to a virtually complete recovery of gait, but when the tumour recurred a year later with a relapse of the gait ataxia, a ventriculoatrial shunt led to only a partial remission. Presumably the gait disturbance now owed more to local brain damage than to hydrocephalus, whereas initially the reverse may have been the case.

It might be objected that recovery of gait after removal of a vermis tumour is merely a reflection of the known capacity of the cerebellum to recover from destructive lesions but this does not account either for improvement after shunting alone, or for the rapidity of gait recovery postoperatively in comparison with the length of time preoperatively that the symptom was present, as in case 2.

Theoretically, hydrocephalus might produce a disturbance of gait from downwards pressure on the rostral vermis by a dilated suprapineal recess, but this does not account for the gait ataxia of third ventricle tumours. Such a situation might be expected to give rise to signs of compression of the quadrigeminal plate which were not noted in these cases. A further objection is that a rostral vermis compression might be expected to give rise to a gait disturbance due to incoordination of the legs tested individually and so by definition be excluded from the category of gait ataxia being discussed here.

There seems to be no special anatomical reason why ventricular dilatation should disturb gait. Possibly it is due not to damage to any particular site in the cerebral hemispheres, but to a diffuse dysfunction of the white matter and hence of the general coordinating structures of the brain at their highest level.

I should like to thank Mr J. J. Maccabe and Mr J. C. M.
Currie for permission to report on patients treated under $\mathrm{D}$ their care and Professor C. D. Marsden for his helpful advice on and criticisms of this paper.

\section{REFERENCES}

Adrian, E. D. (1943). Afferent areas in the cerebellum con nected with the limbs. Brain, 66, 289-315.

Bailey, P., and Cushing, H. (1925). Medulloblastoma cerebelli. A common type of midcerebellar glioma of childhood. . Archives of Neurology and Psychiatry (Chic.), 14, 192224.

Bolk, L. (1906). Das Cerebellum der Säugetiere. Fischer: Haarlem.

Brodal, A. (1969). Neurological Anatomy in Relation to Clinical Medicine. 2nd edn. Oxford University Press: London.

Carrea, R. M. E., and Mettler, F. A. (1947). Physiologic consequences following extensive removals of the cerebellar cortex and deep cerebellar nuclei and effect of $\overrightarrow{0}$ secondary cerebral ablations in the primate. Journal of Comparative Neurology, 87, 169-288.

Chawla, J. C., and Woodward, J. (1972). Motor disorder in 'normal pressure' hydrocephalus. British Medical Journal, $1,485-486$.

Dow, R. S. (1938). The effect of lesions in the vestibular part of the cerebellum in primates. Archives of Neurology and $\infty$ Psychiatry, 40, 500-520.

N

Dow, R. S. (1969). Cerebellar syndromes. In Handbook ד্ Clinical Neurology, vol. 2, pp. 392-431. Edited by P. $\frac{P}{\omega}$ Vinken and G. W. Bruyn. North-Holland: Amsterdam.

Holmes, G. (1917). The symptoms of acute cerebella injuries due to gunshot injuries. Brain, 40, 461-535.

Holmes, G. (1922). The clinical symptoms of cerebellor $\mathbb{D}$ disease and their interpretation. Lancet, 1, 1177-118g 1231-1237; 2, 59-65, 111-115.

Little, J. R., and MacCarty, C. S. (1974). Colloid cysts of the third ventricle. Journal of Neurosurgery, 40, 230-235.

Ojemann, R. G. (1972). Normal pressure hydrocephalus. Scientific Foundation of Neurology, pp. 302-308. Edited by $v$ M. Critchley, J. L. O'Leary, and B. Jennett. Heinemann: London.

Raaf, J., and Kernohan, J. W. (1944). Relation of abnormal collections of cells in the posterior medullary velum of the cerebellum to the origin of medulloblastoma. Archives of Neurology and Psychiatry (Chic.), 52, 163-169.

Snider, R. S., and Stowell, A. (1944). Receiving areas of the tactile, auditory and visual systems in the cerebellum. Journal of Neurophysiology, 7, 331-357.

Victor, M., Adams, R. D., and Mancall, E. L. (1959). A restricted form of cerebellar cortical degeneration occurring in alcoholic patients. Archives of Neurology, 1, 579-688.

Weisenburg, T. H. (1927). Cerebellar localization and its symptomatology. Brain, 50, 357-377. 